\title{
GCU
}

Glasgow Caledonian

University

University for the Common Good

\section{The potential of human induced pluripotent stem cells for modelling diabetic wound healing in vitro}

Martin, Patricia E.; O'Shaughnessy, Erin M.; Wright, Catherine S.; Graham, Annette

Published in:

Clinical Science

DOI:

$10.1042 / C S 20171483$

Publication date:

2018

Document Version

Author accepted manuscript

Link to publication in ResearchOnline

Citation for published version (Harvard):

Martin, PE, O'Shaughnessy, EM, Wright, CS \& Graham, A 2018, 'The potential of human induced pluripotent stem cells for modelling diabetic wound healing in vitro', Clinical Science, vol. 132, no. 15, CS10271483, pp. 1629-1643. https://doi.org/10.1042/CS20171483

\section{General rights}

Copyright and moral rights for the publications made accessible in the public portal are retained by the authors and/or other copyright owners and it is a condition of accessing publications that users recognise and abide by the legal requirements associated with these rights.

Take down policy

If you believe that this document breaches copyright please view our takedown policy at https://edshare.gcu.ac.uk/id/eprint/5179 for details of how to contact us. 


\title{
The potential of human induced pluripotent stem cells for modelling
}

\section{diabetic wound healing in vitro}

\author{
Patricia E Martin, Erin M O'Shaughnessy, Catherine S Wright and Annette Graham* \\ GCU Skin Research Tissue Bank, Department of Life Sciences, School of Health and Life \\ Sciences, Glasgow Caledonian University, Glasgow, G4 OBA, UK
}

*Corresponding author:Professor Annette Graham, Department of Life Sciences, School of Health and Life Sciences, Glasgow Caledonian University, 70 Cowcaddens Road, Glasgow, G4 OBA, UK.

E: Ann.Graham@gcu.ac.uk $\quad T:+44(0) 1413313722 \quad$ F: $+44(0) 1413313208$

Keywords:Wound Healing, Skin, Diabetes Mellitus, Induced Pluripotent Stem Cells, Animal Replacement

Word count:4629 (text); 10,680 (total)

\section{Abstract}

Impaired wound healing and ulceration caused by diabetes mellitus,is a significant healthcare burden, markedly impairs quality of life for patients, and is the major cause of amputation worldwide. Current experimental approaches used to investigate the complex wound healing process often involve cultures of fibroblasts and/or keratinocytes in vitro, which can be limited in terms of complexity and capacity, or utilisation of rodent models in which the mechanisms of wound repair differ substantively from that in humans. However, advances in tissue engineering, and the discovery of strategies to reprogram adult somatic cells to pluripotency, has led to the possibility of developing models of human skin on a large scale. Generation of induced pluripotent stem cells (iPSC) from tissue donated by diabetic patients allows the (epi)genetic background of this disease to be studied, and the ability to differentiate iPSC to multiple cell types found within skin may facilitate the development of more complex skin models; these advances offer key opportunities for improving modelling of wound healing in diabetes, and the development of effective therapeutics for treatment of chronic wounds. (178 words) 


\title{
Perspectives
}

- The cost of diabetic wounds to the National Health Service is estimated to be around $£ 5$ billion per year.

- Rodent models of wound healing fail to recapitulate human wound repair, and in vitro systems using human skin cells can be limited in terms of complexity and capacity

- Reprogramming of cells derived from human donor tissue into pluripotent stem cells may allow the development of fully translational skin models of diabetic wound healing, facilitating the drug discovery process.

\begin{abstract}
AbbreviationsCardiomyocytes (CM): Cluster of differentiation (CD); Checkpoint kinase 1 (CHK1);Clustered regularly interspace short palindromic repeats (CRISPR); CRISPR associated protein 9 (Cas9); Diabetic cardiomyopathy (DCM) Hair follicle-associatedpluripotent (HAP); Human leukocyte antigens (HLA); Human skin equivalents (HSE); Human umbilical vein endothelial cells (HUVECs); Induced pluripotent stem cells (iPSCs); Krueppel-like factor-4 (KIf4); Laminin subunit beta 3 (LAMB) gene deficient Junctional Epidermolysis Bullosa (JEB); Maturity Onset Diabetes of the Young (MODY);Mesenchymal stem cells (MSC); Maternal inherited diabetes and deafness (MIDD); Myc proto-oncogene protein (c-Myc); Non-obese diabetic (NOD);Octamer-binding transcription factor 4(Oct4) Platelet-derived growth factor (PDGF); Recessive Dystrophic Epidermolysis Bullosa (RDEB); Reduction, refinement and replacement (3Rs); Retinal pigment epithelial (RPE); Sex determining region Y-box 2 (Sox2);Transcription activator-like effector nuclease (TALEN) Transforming growth factor- $\beta$ (TGF- $\beta$ ); Type 1/2 diabetes mellitus (T1/2DM); Zinc finger nucleases (ZFNs).
\end{abstract}




\section{Introduction}

Diabetes mellitus is a major global health concern, affecting around 425 million adults worldwide, a figure predicted to rise to 629 million people with diabetes by 2045 (International Diabetes Federation). Type 1 diabetes mellitus (T1DM) is an auto-immune disorder, caused by destruction of insulin-producing pancreatic $\beta$-cells [reviewed in 1], while type 2diabetesmellitus (T2DM) is a polygenic condition characterised by loss of insulin secretion and sensitivity, strongly influenced by environmental factors such as obesity [2]. Single gene disorders, such as neonatal diabetes, Maturity Onset Diabetes of the Young (MODY), and mitochondrial mutations ( $m .3243 \mathrm{~A}>\mathrm{G}$ ), can trigger diabetes in younger age groups [3]. Diabetes mellitus also presents in a number of rare genetic conditions (congenital lipodystrophies [4], Huntington's disease [5], Friedreich ataxia [6], and Turner syndrome [7]), genetic obesity (Prader-Willi syndrome [8], Alstrom syndrome [9] and premature aging conditions such as Werner [10] and Hutchinson-Gilford progeria [11] syndromes. It is a complex metabolic disorder, diagnosed clinically by hyperglycaemia [12] and associated with chronic inflammation, pro-coagulability, impaired fibrinolysis and macro- and microvascular defects, promoting cardiovascular disease (coronary heart disease and stroke) [13], renal dysfunction [14, 15], retinopathies [16], neuropathies[16, 17] and impairment of wound healing in the extremities [17-20].Foot ulceration is major cause of morbidity in type 1 and type 2 diabetes, a significant healthcare burden, and results in markedly impaired quality of life for the patient. Globally, the prevalence of diabetic foot ulceration in 2017 was $6.3 \%(95 \% \mathrm{Cl} 5.4$ to $7.3 \%$ ) [20]anddiabetes is estimated to cause loss of a lower limb (or part thereof) to amputation every 30 seconds worldwide (International Diabetes Federation).

The healing of diabetic woundshas traditionally been investigated using animal models, immortalised cell lines and primary cells. Rodents are often used to examine the complex healing process in vivo, butdo not fully recapitulate the wound repair process in humans[21, 22]. Moreover, the requirement forreduction, refinement and replacement (3Rs) of animal models, and the severity of the procedures involved,mean that a valid replacement is ethically desirable. The use of human primary cells from dermal biopsiesto study wound repair in vitro, particularly in 3-dimensional (3-D) organotypic models, has provided valuable insights into the wound healing process: for example, the incorporation of diabetic patientderived fibroblasts into a 3-D model accurately replicated key features associated with chronic ulcersin vitro and in vivo [23]. This article will review these approaches, and 
highlight recent advances in reprogramming of adult somatic cells to pluripotency, which offer exciting opportunities to develop improved models for diabetic wound healing.

\section{Wound healing: acute and chronic wounds}

Wound healing involves four distinct, but overlapping phases: haemostasis, inflammation, proliferation and remodelling (Table 1) [24-26]. Wound clotting is followed by reepithelisation at the wound edge around 12-18h post-wounding; concomitantly, a granulation tissue is formed by dermal fibroblasts at the wound margin, some of which convert to contractile myofibroblasts. Bone-marrow derived mesenchymal stem cells contribute to granulation tissuewhich contains a dense network of capillaries, and contraction reduces the surface area requiring re-epithelisation [22-26]. Neutrophils are recruited to the site of wounding, to kill microorganisms, followed by macrophages which phagocytose cell and matrix debris; these inflammatory cells then either die or leave the site of injury, aiding final resolution of the wound.

Chronic (non-healing) wounds in diabetic patients are characterised by persistent, unresolved inflammation, mediated predominantly by infiltrating neutrophils, with a significant impairment in local bacterial invasion control. Diabetic conditions, such as inflammation, hyperglycaemia and hyperlipidaemia induce epigenetic changes, promoting an inflammatory macrophage phenotype [27] which fails to transition to a pro-healing phenotype within the local wound environment [28]. Keratinocytes at the epidermal edge are hyper-proliferative, adjacent to an ulcer base which contains exudate and necrotic debris; dermal fibroblasts appear senescent and recalcitrant to the migratory stimulant, transforming growth factor- $\beta$ (TGF- $\beta$ ), and few myofibroblasts are present. Instead of granulation tissue, vessels are surrounded by fibrin cuffs and do not form an effective network, rendering the wound poorly vascularised [26, 29]. Advanced glycation endproducts act in concert with inflammatory mediators, and commit fibroblasts and vascular cells to apoptosis, contributing to the demise of granulation tissue [30].

\section{Primary cells, immortalised cell lines and skin explants}

The simplest cell-based model of wound healing in vitro involves culturing a monolayer ofprimary fibroblasts, keratinocytes or immortalised cells (e.g.HaCaT keratinocytes) and introducing a 'scrape' across the surface using a sterile pipette tip: the 'scratch' wound assay [31, 32, 33]. Migration of cells across the wound can be measured using static or time-lapse microscopy, and the expression of proteins involved in inflammation, migration, 
proliferation, differentiation and remodelling of the extracellular matrix investigated (Table 1). Variability can be introduced into the system through changes in oxygen tension, the addition of drugs, growth factors or cytokines, or the use of extracellular matrices and specialised culture surfaces. These models can also be used to examine differences between healing and non-healing wounds, using normal and diabetic cells and altered tissue culture environments [23, 34-38].

Since the 1970s there has been increasing interest in generating skin constructs which are physiologically relevant, capable of mimicking barrier formation, immune and sensory functions [39, 40]. Co-cultures of keratinocytes with other cell types, including immune cells and dermal fibroblasts, are often used for investigations of wound healing, but these cannot entirely replicate the cell-cell and cell-matrix interactions found in a 3-dimensional environment. The use of dermal fibroblasts encapsulated in gel/matrix, combined with differentiated keratinocytes forming a 3-D epidermis, often at the air-liquid interface, can address some of these limitations, and are useful for modelling changes in keratinocyte function, cytokine release after drug treatment, metabolism, irritation and sensitisation, and skin aging[23, 41-46]. Tissue-engineered skin products have also been used clinically (e.g. Apligraf, Dermagraft) to aid wound repair, particularly to provide barrier function [47, 48]. However, the complexity of skin tissue, including the roles of a number of specialised cell types such as melanocytes, immune cells (macrophages, Langerhans cells, T cells, dendritic cells) and stem cell niches, and of skin appendages (hair follicles), sweat and sebaceous glands, obviously cannot be wholly recapitulated in cultures of just keratinocytes and/or fibroblasts.

Vascularisation can be achieved by the addition of endothelial cells, stimulated to form capillaries within the dermal environment, and to form a vascular network when supported by a suitable scaffold and perfusion system [49]. Other approaches have focused on the introduction of melanocytes, to study melanin transfer to keratinocytes, allowing studies of photoprotection and acquired (drug-induced) hyper-pigmentation [50], and the inclusion of hair follicles, sweat and sebaceous glands, to facilitate study of cosmetics, treatments for alopecia and sebo-regulating drugs [40]. The addition of immune cells, innervation of skin models, and introduction of the hypodermis (adipose tissue) are desirable for effective drug and allergen testing.

At present, however, it can be difficult to achieve some of these outcomes with primary cells derived from human skin biopsies, due to their limited availability and/or growth potential 
$[40,50]$.Tissue biopsies are small, making it possible to isolate and expand in culture only the most numerous cell types, i.e. dermal fibroblasts and epidermal keratinocytes [50], and a negative relationship exists between the extent of expansion of keratinocytes in culture, and their longevity in a tissue-engineered epidermis [51, 52]. Minority skin cell populations, such as Merkel cells, cannot be greatly expanded in culture [50] and many cell types found in skin, such as macrophages, are transient, entering the skin only in response to a pathological challenge. While the use of multiple donors is possible, this approach ignores individual responses, and can greatly complicate data analysis [50].Immortalisation of primary cell lines can solve some of these problems [32, 33, 53], but the constitutive expression of oncogenes can markedly influence cellular phenotype and proliferation rate, which maylimit their value for wound healing studies and negate their usefulness clinically.

\section{Animal models in wound healing studies}

Animal models have been used to replicate the complexity of wound healing in vivo. Mice are the most widely used species for in vivo studies, although other larger species, such as pig, more closely mirror human wound healing and are often used in pre-clinical trials [29, 54]. The epithelial architecture, extracellular matrix, vascular networks and innervation in porcine skin are similar to those in human skin, but swine are difficult to house in most vivariums, do not lend themselves easily to in vivo imaging experiments and are not fully characterized at cellular and physiological levels. Moreover, the availability of swinespecific reagents, such as antibodies and growth factors, may be restricted. Acute wound healing in rodents is commonlymonitored following excisional (biopsy punch, surgical scissors or laser) or full thickness incisional (scalpel) wounds, made to the foot, thigh or back, although considerable variance exists as to the size and number of wounds per animal, the tools employed, the presence of occlusive dressings, splints, or non-occlusive bandages of varying types, and the use of sutures to close the wound margins $[29,54]$.

Chronic wound healing models involve introducing an acute wound, usually in a murine model, within the clinical context involved, such as diabetes or ischaemic injury [22, 29] Type 1diabetes mellitus can be induced by transgenic breeding (e.g. non-obese diabetic (NOD) mice),spontaneous autoimmunity, chemical ablation of pancreatic $\beta$-cells (streptozotocin) or viral infection[55,56]. High fat feeding or genetic deletion is often used to induce a condition resembling T2DM in mice [56]: the most widely used models of T2DM are leptin $(\mathrm{ob} / \mathrm{ob})$ or leptin receptor $(\mathrm{db} / \mathrm{db})$ deficient rodents, which become obese around six weeks of age, and subsequently develop T2DM with marked delays in wound healing. 
Polygenic diabetic strains, such as NONcNZO10/LtJ mice which model human metabolic syndrome and obesity-induced diabetes, have also been developed which exhibit defects in wound repair [56-58].

Despite the common use of animal models to study acute and chronic wound healing, physiological differences between species need to be considered [22, 59,60]. Mouse and human skin have markedly different architecture, responsiveness and functionality, due to differences in thickness, hair density and appendages; murine skin is also largely devoid of sweat glands. Murine subcutaneous tissue has a thin layer of muscular tissue, the panniculus carnosus, which has substantive contractive potential; up to $90 \%$ of excisional wounds in mice close by contraction. By contrast, re-epithelization and formation of granulation tissue is the predominant mechanism of cutaneous wound healing in human dermis $[22,59,60]$. Attempts have been made to address this issue, by splinting excision wounds to more closely replicate wound healing in human skin; topical administration of platelet-derived growth factor (PDGF), for example, fails to promote closure of a splinted wound by re-epithelisation in $\mathrm{db} / \mathrm{db}$ mice [61], despite its efficacy in othermurine models of wound healing. While wound splinting does allow histologic monitoring of wound bed granulation, the healing process still does not fully mimic human wound healing [22, 59, 60]. Outcomes from wound healing studies in rodents may therefore not be fully translatable to humans, possibly explaining the dearth of effective treatments currently available.

An alternativein vivo approach involves thegeneration of humanised mouse models. Shunmugamet al (2015) grafted human skin biopsies from elective abdominoplasty surgery onto athymic $(n u / n u)$ mice for three months, before inducing a excision wound into the graft, and monitoring wound healing using near infra-red fluorescent imaging [62]. Human skin constructs have also been transplanted onto immunodeficient mice: a 3-D matrix, enriched with fibrin from human blood plasma was seeded with human fibroblasts to form a dermis, before adding an epidermal layer using human keratinocytes [63]; the same group have also described a humanised model of delayed wound healing in streptozotocin-induced diabetic mice [64].It is clear, however, that all of these approaches to the study of wound healing in animals are classified as 'severe', likely to cause pain and distress: an ethical imperative exists to develop an in vitro translational model of human wound healing. 


\section{Induced pluripotent stem cells}

The concept of cell plasticity originates from the groundbreaking work of John Gurdon in the 1960s [65-67], culminating in the award of the Nobel Prize in Physiology or Medicine (2012) jointly with Shinya Yamanaka, more than forty years later; Yamanaka, together with Kazutoshi Takahashi, discovered how mature somatic cells can be reprogrammed to become pluripotent stem cells [68-70]. Induced pluripotent stem cells (iPSCs) can be derived from individuals with differing genetics, disease conditions or ethnic origins, and differentiated to cell types of the three germ layers, revolutionising research and drug discovery, and increasing the prospect of personalised regenerative medicine [68-74]. While early reprogramming strategies used retroviral and lentiviral vectors to deliver the transcription factors (e.g. Oct4, Sox2, Klf4, c-Myc) required to reprogram adult somatic cells to the pluripotent state [68-71], current reprogramming approaches avoid genomic integration [75], by utilising integration-free strategies such as Sendai virus, mRNA, microRNA, episomal vectors and non-nucleotide based methods [76-79] (Figure 1).

Induced pluripotent stem cells are characterised by the ability to self-renew indefinitely, stable karyotype, and the potential to differentiate into cell types of the ectoderm, mesoderm and endoderm [80-83]. Robust protocols are then needed to differentiate iPSCs into cells and tissues of the desired type, characterised by function and/or expression of key biomarkers, and the presence of the disease phenotype; disease mechanisms can then be investigated, or potential therapeutics tested [80-83]. Age and/or sex matched control donor material can be subjected to equivalent reprogramming and differentiation procedures; alternatively,isogenic controls can be generated by gene correction of the pluripotent cells, using clustered regularly interspace short palindromic repeats (CRISPR).CRISPR associated protein 9 (Cas9), zinc finger nucleases (ZFNs) or transcription activator-like effector nuclease (TALEN) systems [84, 85].

The direct reprogramming and trans-differentiation of somatic cells to specialised cell types, including those involved in diabetes and wound healing, has also been described; this approach bypasses the pluripotent stage and may therefore prove safer for cell therapy [8688].Primitive stem cells, such as hair follicle-associated-pluripotent (HAP) stem cells resident in the skin, also have potential to be converted to keratinocytes and melanocytes for therapeutic epidermal regeneration without the risk of tumour formation [89]. These approaches do not, however, offer the same opportunities for expansion and banking as conversion to pluripotency. 


\section{Pluripotent stem cells and generation of human skin constructs in vitro}

The ability to model the complex interactions of whole tissues and organs using entirely human biology is a major goal for tissue engineering and stem cell research, and may eventually lead to the production of whole organs for transplantation [90]. Indeed, dermatology may be the ideal context for application of iPSC-based therapies, as it is readily accessible and easy to monitor, and excision is possible if adverse side effects occur [91]. Many of these challenges are also relevant to the development of accurate representations of tissue for disease modelling, including skin for wound healing assays.

The generation of iPSCs from dermal fibroblasts, keratinocytes, melanocytes and dermal papilla cells is established, with reprogramming occurring at higher efficiency in keratinocytes and melanocytes than in fibroblasts [39, 40,50]. Moreover, iPSCs have been derived from patients with genetic skin disorders, including Type VII collagen-deficient Recessive Dystrophic Epidermolysis Bullosa (RDEB), laminin subunit beta 3 (LAMB) gene deficient Junctional Epidermolysis Bullosa (JEB), Epidermolysis Bullosa simplex with a dominant R125C keratin 14 mutation, and from gene corrected RDEB fibroblasts[92-95]. Regeneration of human epidermis in vivo using iPSCs is yet to be achieved, but the potential of this approach was recently demonstrated by Hirsch et al (2017) who utilised autologous transgenic keratinocyte cultures to renew the epidermis in a seven year old child suffering from severe JEB [96]. In this case, the epidermis was sustained by a limited number of long-lived stem cells or holoclones, self-renewal of which provided progenitor cells capable of replacing terminally differentiating keratinocytes [96].

Notably, it seems that reprogrammed cells retain epigenetic features of the cell type of origin (although these disappear on continued passaging) and it has been suggested that this residual epigenetic memory may facilitate differentiation back to the corresponding original cell type [91, 97-99]. Intriguingly, the process of reprogramming down-regulates senescent pathways, elongates telomeres and restores mitochondrial function [100-102] effectively 'rejuvenating' the cellular phenotype; indeed, 'rejuvenated' fibroblasts can also be generated from iPS cells derived from very old patients, offering new strategies for treatment of chronic wounds in the elderly [91, 102].

Keratinocytes, fibroblasts and melanocytes have been successfully derived from human iPSCs, and iPSCs can be differentiated into immune cells (T-lymphocytes, macrophages and dendritic cells), endothelial and smooth muscle cells, Schwann cells and peripheral 
neurons [39, 40, 50, 103-107] and iPSC-derived ectodermal precursor cells can contribute to hair follicle morphogenesis in vivo [108]. Thus, iPSC-derived skin cells have huge potential for skin tissue engineering, and for the development of in vitro skin models for healthy and diseased skin, and inacute and chronic wound healing studies.

Human skin equivalents (HSE) have been generated using iPSC-derived fibroblasts and/orkeratinocytes[106-109]. The transcriptome of iPSC-derived keratinocytes proved very similar to primary healthy human keratinocytes, while incubation of iPSC-derived keratinocytes at an air/liquid interface resulted in epidermal stratification and the development of a functional permeability barrier [109]. Itoh et al (2011) generated an in vitro 3-D skin equivalent, using a type I collagen matrix to support iPSC-derived fibroblasts in the dermis, and iPSC-derived keratinocytes to form an epidermis, and demonstrated normal morphology, stratification and terminal differentiation at the air-liquid interface [107]. Enriched complexity was achieved by Gledhill et al (2015), by introduction ofiPSC-derived melanocytes, responsible for both skin colour and protection against ultraviolet radiation, into a 3-D HSE [50]. A collagen I matrix was seeded with iPSC-derived fibroblasts, to support iPSC-derived keratinocytes and melanocytes. The iPSC-derived melanocytes localised to the basal layer, extending dendrites into the suprabasal layer of the epidermis, and produced melanin which was taken up by iPSC-derived keratinocytes [50].

Endothelial and smooth muscle cells, differentiated from human iPSC, cooperate to enhance formation of tubular networks in vitro, and in athymic nude mice; cotransplantation of these cells markedly increased neovascularisation and wound healing in a murine dermal wound model [110] compared to primary somatic cells or implantation of differentiated endothelial cells alone. Vascularisation of HSE, comprised of primary neonatal dermal fibroblasts and keratinocytes, has also been achieved using iPSC-derived endothelial cells $[39,110]$. The formerstudy focused on developing an in vitro platform capable of recapitulating the cutaneous microcirculation, allowing perfusion and evaluation of endothelial barrier function [39]. A 3-D printing technology was used to create the desired patterns of vasculature, including inlet-outlet tubes for perfusion, from sacrificial microchannels of cross-linked alginate embedded in a dermis consisting of uncrosslinked collagen I gel and fibroblasts. Within this context, the diffusion barrier function provided by iPSC-derived endothelial cells proved similar to that provided by human umbilical vein endothelial cells (HUVECs) [39]. 
Finally, using a rather different approach Zhang et al (2015) developed patient-specific mesenchymal stem cells (MSC) from human iPSC, and isolated the exosomes released into the extracellular milieu [111]. Exosomes, positive for cluster of differentiation (CD) 9, CD63, CD8a, are nano-sized vesicles (30-100nm in diameter) that contain proteins, mRNA and micro RNA, and are thought to facilitate wound healing in a paracrine manner. In this study, exosomes derived from iPSC-MSCs enhanced the proliferation and migration of fibroblasts and human umbilical vein endothelial cells (HUVECs), increased the secretion of collagen and elastin and promoted the formation of tubular networks of endothelial cellsin vitro; in a rat wound model, the introduction of iPSC-MSC derived exosomes enhanced wound repair, collagen synthesis and angiogenesis [111].

Thus, the technology exists for use of pluripotent stem cell-based systems in creating physiologically relevant and translatable3-D models of human wound healingin vitro,toaid the development of novel therapeutics, identifying effective treatments and reducing attrition in the later and more costly stages of drug development. Some barriers exist, however, to widespread adoption of these models. Financial constraints may ultimately be addressed by optimisation of cell culture, reprogramming and differentiation protocols; the labour intensive nature of the work may also be resolved by high throughput automated approaches [112]. Other limitations include variability among iPSC cell lines [113] and genomic instability $[114,115]$. The establishment of selection criteria for iPSC and iPSCderived cells, such as cell-specific markers, assessment of proliferation rate and lifespan, and investigation of the transcriptome $[112,113]$,can help to minimise variability, while limiting replication stress during reprogramming, either genetically by targeting checkpoint kinase 1 (CHK1) or by using nucleoside supplementation, can help to reduce genomic instability [115]. The quality of 3-D skin constructs should also meet key criteria such as histological morphology, cell viability and barrier function [106-109].

\section{Pluripotent stem cells derived from diabetic individuals: disease modelling}

Induced pluripotent stem cells have been derived from individuals with monogenic forms of diabetes, and from patients with type 1 and type 2 diabetes mellitus, facilitating research into multiple aspects of the complex pathogenesis of these disorders (Table 2), although it is clear that the potential for utilisation of these cells in studies of diabetic wound healing is yet to be fully realised.The autoimmunity that arises in T1DM results from a complex interaction between genetic and immunologic factors [1]. Risk of T1DM progression is polygenic, with a large number of genes conferring small risk effects, and a small number of 
genes having large effects, most particularly the human leukocyte antigens (HLA) DR/DQ alleles (e.g. DRB1*03-DQB1 ${ }^{*} 0201$ (DR3) or DRB1*04-DQB1 ${ }^{*} 0302$ (DR4) [1]. To date, genomic wide association studies have identified at least 75 independent genetic loci for T2DM although whether all of these variants are causal is not known, and their mechanism of action requires further clarification [2, 136, 137]. Further, most of the common variants identified confer a relatively low risk of T2DM (odds ratio 1.0 to 1.4) and explain only 10$15 \%$ of the heritability of this disease $[136,137]$. These complex inheritance patterns highlight the importance of generating iPSCs from diabetic individuals to develop skin wound healing models in vitro, although they may effectively negate the possibility of generating isogenic controls.

Epigenetic changes, including those due to an early metabolic insult, are also critical in the development of T2D: changes in DNA methylation markers have been identified in blood samples and pancreatic islets from T2D patients [137]. At present, it is not clear whether these epigenetic changes would be retained during reprogramming to pluripotency, a process which induces metabolic changes, including a shift from oxidative to glycolytic metabolism of glucose. However, Harvey et al (2018) recently demonstrated retention of metabolic memory in human iPSC: in response to challenge with reduced oxygen concentration, iPS cell lines did not respond appropriately, indicating that metabolism had not been functionally reprogrammed, failing to recapitulate the metabolic responsiveness of embryonic stem cells [138].

This may pose a significant problem in cell replacement therapy designed to correct defects in diabetic patients; for example, the generation of functional insulin-secreting pancreatic $\beta$ cells from iPSCs, for potential cell replacement therapy represents a key goal for treatment of type 1 and type 2 diabetes [139].Induced pluripotent stem cells have been generated from fibroblasts from ulcerated skin of diabetic foot ulcer patients, and compared with those from non-ulcerated diabetic skin and from healthy individuals: all of the skin fibroblasts were reprogrammed to IPSC with similar efficiencies, indicating that even repair-deficient fibroblasts may be useful therapeuticsfor wound healing [134]. Human iPS cells from Type 1 diabetic patients have also been differentiated into early vascular cells and mature endothelial cells which can assemble into 3-D networks when embedded in engineered matrices, incorporate into developing zebrafish vasculature, and may prove to be a useful in vascular repair for diabetic patients [133]. The challenges currently facing this type of 
regenerative cell therapy, which are outwith the scope of this review, have been recently and comprehensively reviewed $[73,112-115,140]$.

Arguably, however, retention of the diabetic epigenome, together with the presence of genetic variations which increase the risk of T2D, may facilitate the development of authentic models, including wound healing, of this disease in vitro. To date, dermal fibroblasts, from patients with the mitochondrial A3243G mutation, associated with maternal inherited diabetes and deafness (MIDD) have been used to generate heteroplasmic iPSC clones for studies of mitochondrial function [117]. Isogenic iPS clones with either high levels of this mutation or undetectable levels of the mutation, from the same individuals; complex I activity, mitochondrial respiration and ATP production were compromised in some of the mutation-high clones, while those from the mutation-undetectable clones were similar to those of iPS cells from healthy subjects [117]. Induced pluripotent stem cell clones derived from patients with the same mitochondrial mutation were differentiated into retinal pigment epithelial (RPE) cells [141]. The RPE cells contained morphologically abnormal mitochondria and melanosomes, and marked functional defects in phagocytosis of photoreceptor outer segments, facilitating dissection of the complex tissue-specific pathology associated with this mitochondrial mutation [141]. Insulin-resistant iPS cells, derived from patients with genetic defects in the insulin receptor, have also been shown to exhibit altered mitochondrial size and function, and changes in cellular metabolism [127].

Thepower of disease modelling using human iPSC is clearly illustrated by Drawnel et al (2014), who utilised this approach to develop a patient-specific iPSC model and drugscreening platform for diabetic cardiomyopathy (DCM) [135]. Firstly, the authors developed a surrogate DCM phenotype; iPSC-derived cardiomyocytes (CM), which more closely resemble neonatal CMs, were induced to an adult pattern of metabolic activity in two differing experimental conditions. A maturation media, supplemented with insulin and fatty acids, which requires the cells to maintain ATP by fatty acid $\beta$-oxidation, was used to mimic the metabolic substrate of adult ventricular CMs, while the re-introduction of glucose, and hormonal mediators of diabetes (endothelin-1, cortisol) generated a pattern of gene expression associated with hypertrophic stress, and recapitulated the DCM phenotype in vitro. Secondly, iPSC cells were derived from patients with two extreme DCM phenotypes: fast progression to cardiovascular disease (within 5y of diagnosis of diabetes) and slow progression (no cardiovascular disease despite 15y of T2D). Dermal fibroblasts were reprogrammed to patient-specific iPSC with normal karyotype and differentiation potential; 
the patient-specific iPSC-derived cardiomyocytes, cultured in the presence of maturation media, displayed a basal cardiomyocyte phenotype which corresponded to the clinical status of the original donor, in the absence of diabetic stimulus, suggesting retention of epigenetic factors. Suppression of the diabetic phenotype in the environmental model of DCM was then successfully employed as a screenable endpoint for small molecules which could rescue the phenotype of patient-specific cardiomyocytes [135]. An equivalent approach to modelling diabetic wound healing could prove equally insightful and valuable therapeutically.

\section{Concluding remarks:challenges for the future}

The development of robust protocols for reproducible derivation of iPSC from diabetic patients, and for differentiation of iPSC into the multiple cell types found within human skin, is increasingly being performed using chemically defined and animal-origin free cell culture conditions; this is key in limiting batch variability, reducing the use of animal models and animal-derived materials, and in improving models of human diabetic wound healing. These goals rely on the altruistic donation of tissue from patients, a process facilitated by creation of large Biobanks (or Biorepositories) associated with universities, research organisations and the National Health Service in the UK. Biobanks provide ethically donated human tissue (normal and diseased), and associated anonymised clinical data, for individual studies or to smaller research tissue banks (e.g. GCU Skin Research Tissue Bank: www.gcu.ac.uk/hls/research/researchgroups/gcuskinresearchtissuebank/), dedicated to the study of human diseases involving complex genetic backgrounds. The derivation of diabetic pluripotent cells, capable of indefinite self-renewal and expansion, and differentiation into multiple lineages, may provide new insight into disease mechanisms and hold considerable promise for the development of effective therapeutics for treatment of chronic wounds in diabetic individuals

\section{Acknowledgments}

The GCU Skin Research Tissue Bankhas receiveda project grant from Animal Free Research.Animal Free Research is the UK's leading non-animal biomedical research charity that exclusively funds and promotes human-relevant research that replaces the use of animals whilst supporting the progress of medicine. 
Table 1: Summary of the stages of wound repair

\begin{tabular}{|c|c|c|c|}
\hline Stage & Main processes & Key molecules & REF \\
\hline Haemostasis & $\begin{array}{l}\text { Platelet-dependent vasoconstriction } \\
\text { and fibrin clot formation }\end{array}$ & $\begin{array}{l}\text { ADP, ATP, GDP, 5-HT } \\
\text { P2Y } 12 \text { receptor axis } \\
\text { Integrin } \alpha \text { llb } \beta 3 \\
\text { Von Willebrand Factor } \\
\text { Fibrinogen }\end{array}$ & [24] \\
\hline Inflammation & $\begin{array}{l}\text { Release of cytokines } \\
\text { Invasion of inflammatory cells } \\
\text { (neutrophils, monocytes) }\end{array}$ & $\begin{array}{l}\text { Transforming growth } \\
\text { factor- } \beta \text { (TGF- } \beta 1 \text {, } \\
\beta 2, \beta 3 \text { )/TGF } \beta \text { receptor } \\
\text { I/II } \\
\text { Platelet-derived growth } \\
\text { factor (PDGF) }\end{array}$ & {$[22,25,26]$} \\
\hline Proliferation & $\begin{array}{l}\text { Dermis } \\
\text { Macrophages and fibroblasts release } \\
\text { growth factors } \\
\text { Migration of fibroblasts and } \\
\text { proliferation } \\
\text { Biosynthesis and deposition of matrix } \\
\text { proteins } \\
\text { Angiogenesis } \\
\text { Epidermis } \\
\text { Migration, proliferation and } \\
\text { differentiation of keratinocytes } \\
\text { Contributions from hair follicle stem } \\
\text { cells/interfollicular epidermal stem cells }\end{array}$ & $\begin{array}{l}\text { TGF- } \beta \\
\text { Matrix } \\
\text { metalloproteinases } \\
\text { (MMPs) } \\
\text { Fibronectin, type (III) } \\
\text { collagen, type (I) } \\
\text { collagen } \\
\text { Vascular Endothelial } \\
\text { growth Factor (VEGF) }\end{array}$ & {$[22,25,26]$} \\
\hline Remodelling & $\begin{array}{l}\text { Wound fibroblasts adopt a contractile } \\
\text { myofibroblast phenotype } \\
\text { Degradation and reorganisation of the } \\
\text { extracellular matrix } \\
\text { Apoptosis of a variety of cell types } \\
\text { Wound contraction }\end{array}$ & $\begin{array}{l}\text { TGF- } \beta \\
\text { MMPs } \\
\text { Type (I) collagen }\end{array}$ & {$[22,25,26]$} \\
\hline
\end{tabular}


Table 2: Establishment and utilization of iPS cells from diabetic patients

\begin{tabular}{|c|c|c|c|}
\hline Mutation & $\begin{array}{l}\text { Patient } \\
\text { characteristics }\end{array}$ & Uses & REF \\
\hline $\begin{array}{l}\text { Mitochondrial tRNA } \\
\text { (A3243G) }\end{array}$ & $\begin{array}{l}\text { Maternal } \\
\text { Inhibited } \\
\text { Diabetes and } \\
\text { Deafness } \\
\text { (MIDD) }\end{array}$ & $\begin{array}{l}\text { Analysis of mitochondrial } \\
\text { (dys)function associated } \\
\text { with diabetes }\end{array}$ & {$[116,117]$} \\
\hline Glucokinase (GCK) & $\begin{array}{l}\text { Maturity Onset } \\
\text { Diabetes of the } \\
\text { Young (MODY) } \\
2\end{array}$ & $\begin{array}{l}\text { Defects in insulin } \\
\text { production and gene } \\
\text { correction. }\end{array}$ & [118] \\
\hline $\begin{array}{l}\text { Hepatocyte nuclear } \\
\text { factor (HNF) } 1 \mathrm{~A}\end{array}$ & MODY 3 & $\begin{array}{l}\text { Defects in insulin } \\
\text { production }\end{array}$ & {$[118,119]$} \\
\hline $\begin{array}{l}\text { Pancreatic and duodenal } \\
\text { Homeobox } 1 \text { (PDX1) }\end{array}$ & MODY4 & $\begin{array}{l}\text { Generation of glucose- } \\
\text { responsive insulin } \\
\text { secreting cells }\end{array}$ & [120] \\
\hline Heterozygous PDX1 & MODY4 & $\begin{array}{l}\text { Pathogenesis of MODY4 } \\
\text { and T2DM }\end{array}$ & [121] \\
\hline HNF1B & MODY5 & $\begin{array}{l}\text { Pancreatic hypoplasia } \\
\text { Development of pancreatic } \\
\beta \text {-cells }\end{array}$ & $\begin{array}{l}{[122]} \\
{[123]}\end{array}$ \\
\hline $\begin{array}{l}\text { Heterozygous activating } \\
\text { mutation inpotassium } \\
\text { inwardly-rectifying } \\
\text { channel, subfamily J, } \\
\text { member } 11 \text { (KCNJ11) }\end{array}$ & MODY13 & Pathogenesis of MODY13 & [124] \\
\hline $\begin{array}{l}\text { Arginine vasopressin } \\
\text { (AVP) gene carrying an } \\
\text { adFND1 causing variant } \\
\text { in exon } 1\end{array}$ & $\begin{array}{l}\text { Autosomal } \\
\text { dominant } \\
\text { familial neuro- } \\
\text { hypophysealdia } \\
\text { betesinsipidus } \\
\text { (adFND1) }\end{array}$ & Pathogenesis of adFND1 & [125] \\
\hline $\begin{array}{l}\text { Activating germline } \\
\text { mutation in signal } \\
\text { tranducer and activator of } \\
\text { transcription (STAT3) }\end{array}$ & $\begin{array}{l}\text { Neonataldiabete } \\
\mathrm{s}\end{array}$ & $\begin{array}{l}\text { Pancreaticendodermaldev } \\
\text { elopment }\end{array}$ & [126] \\
\hline $\begin{array}{l}\text { Insulin receptor } \\
\text { mutations }\end{array}$ & $\begin{array}{l}\text { Genetic insulin } \\
\text { resistance }\end{array}$ & Mitochondrial (dys)function & [127] \\
\hline $\begin{array}{l}\text { Loss of paternal gene } \\
\text { expression in an } \\
\text { imprinted (epigenetic) } \\
\text { interval on 15q11.2-q13 }\end{array}$ & $\begin{array}{l}\text { Obesity (Prader- } \\
\text { Willi syndrome) }\end{array}$ & $\begin{array}{l}\text { Pathogenesis of Prader- } \\
\text { Willi syndrome and } \\
\text { associated morbidities }\end{array}$ & [128] \\
\hline Lamin A/C (LMNA) & $\begin{array}{l}\text { Hutchinson } \\
\text { Gilford Progeria } \\
\text { syndrome } \\
\text { (HGPS) } \\
\text { (accelerated } \\
\text { aging, }\end{array}$ & Pathology of HGPS & [129] \\
\hline
\end{tabular}




\begin{tabular}{|c|c|c|c|}
\hline & $\begin{array}{l}\text { lipodystrophic } \\
\text { insulin } \\
\text { resistance) }\end{array}$ & & \\
\hline $\begin{array}{l}\text { Berardinelli-Seip } \\
\text { congenital } \\
\text { lipodystrophy } 2 \\
\text { (BSCL2/SEIPIN) } \\
\text { mutations }\end{array}$ & $\begin{array}{l}\text { Congenital } \\
\text { generalized } \\
\text { lipodystrophy }\end{array}$ & $\begin{array}{l}\text { Defects in adipogenesis } \\
\text { and pathology of human } \\
\text { lipodystrophy }\end{array}$ & [130] \\
\hline- & $\begin{array}{l}\text { Fulminant type } \\
1 \text { diabetes }\end{array}$ & $\begin{array}{l}\text { Cytokine-induced apoptotic } \\
\text { reactions of } \beta \text {-like insulin } \\
\text { producing cells }\end{array}$ & [131] \\
\hline - & Type 1 diabetes & $\begin{array}{l}\text { Expression of pancreas- } \\
\text { specific microRNAs }\end{array}$ & [132] \\
\hline - & Type 1 diabetes & $\begin{array}{l}\text { Autologous vascular } \\
\text { therapy }\end{array}$ & [133] \\
\hline - & $\begin{array}{l}\text { Diabetic foot } \\
\text { ulcer } \\
\text { Type } 2 \text { diabetes }\end{array}$ & $\begin{array}{l}\text { Future regenerative } \\
\text { therapies for diabetic foot } \\
\text { ulcer }\end{array}$ & [134] \\
\hline- & Type 2 diabetes & $\begin{array}{l}\text { Disease modelling and } \\
\text { drug screening for diabetic } \\
\text { cardiomyopathy }\end{array}$ & [135] \\
\hline
\end{tabular}

\section{Figure 1: Modelling of diabetic wound repair using induced pluripotent stem cells}

Patient skin biopsies (diabetic and non-diabetic) can be used to supply frozen tissue or wax embedded sections for interrogation by Q-PCR, immunohistochemistry or immunofluorescence; alternatively, primary fibroblasts and keratinocytes isolated from the dermis and epidermis can be utilised directly in 2- and 3-dimensional studies of wound healing, or reprogrammed to pluripotency by delivery (viral, episomal plasmids, mRNA, microRNA) of combinations of transcription factors such as octamer binding transcription factor 4 (Oct4), Krueppel-like factor-4 (Klf4), sex determining region Y-box 2 (Sox2), Myc proto-oncogene protein (c-Myc), lin-28 homolog A (Lin28) or Nanoghomeobox (Nanog). Retention of epigenetic 'memory' can be assessed from gene expression profiles, persistence of donor-cell gene expression and ease of differentiation and both 'memory' and 'non-memory' iPSC which are capable of indefinite self-renewal and expansion can be banked; iPSC cell lines can also undergo targeted gene correction by CRISPR/Cas9, TALEN or ZFN systems. Established and developing protocols can be used to differentiate iPSC into a range of cell types found within human skin (fibroblasts, keratinocytes, melanocytes), and immune cells (T-lymphocytes, macrophages, dendritic cells and neutrophils), endothelial and smooth muscle cells, Schwann cells and peripheral neurons. When combined with tissue engineering methodologies, utilisation of skin models derived 
fromdiabetic iPSC may provide new insight into disease mechanisms, and facilitate the development of effective therapeutics for treatment of chronic wounds in diabetic individuals.

\section{References}

1. Morran MP, Vonberg A, Khadra A, Pietropaolo M (2015) Immunogenetics of type 1 diabetes mellitus. Mol Aspects Med 42:42-60. doi: 10.1016/j.mam.2014.12.004

2. Zaccardi F, Dhalwani NN, Papamargaritis D, Webb DR, Murphy GJ, Davies MJ, Khunti K (2017) Nonlinear association of BMI with all-cause and cardiovascular mortality in type 2 diabetes mellitus: a systematic review and meta-analysis of 414,587 participants in prospective studies. Diabetologia 60(2):240-248 doi: 10.1007/s00125016-4162-6.

3. Hattersley AT, Patel KA (2017) Precision diabetes: learning from monogenic diabetes. Diabetologia 60(5):769-777. doi: 10.1007/s00125-017-4226-2.

4. Patni N, Garg A (2015) Congenital generalized lipodystrophies - new insights into metabolic dysfunction. Nat Rev Endocrinol 11(9):522-534. doi:10.1038/nrendo.2015.123.

5. Schonberger SJ, Jezdic D, Faull RL, Cooper GJ (2013) Proteomic analysis of the human brain in Huntington's Disease indicates pathogenesis by molecular processes linked to other neurodegenerative diseases and to type-2 diabetes. J Huntingtons Dis 2(1):89-99. doi:10.3233/JHD-120044.

6. McCormick A, Farmer J, Perlman S, Delatycki M, Wilmot G, Matthews K, Yoon G, Hoyle G, Subramony SH, Zesiewicz T, Lynch DR, McCormack SE (2017) Impact of diabetes in the Friedreich ataxia clinical outcome measures study. Ann ClinTransINeurol 4(9):622-631. doi: 10.1002/acn3.439.

7. Levitsky LL, Luria AH, Hayes FJ, Lin AE (2015) Turner syndrome: update on biology and management across the life span. CurrOpin Endocrinol Diabetes Obes 22(1):6572. doi:10.1097/MED0000000000000128.

8. Stagi S, Lapi E, Pantaleo M, Chiarelli F, Seminara S, de Marmtino M (2014) Type II diabetes and impaired glucose tolerance due to severe hyperinsulinaemia in patients with 1p36 deletion syndrome and a Prader-Willi-like phenotype. BMC Med Genet 15:16. doi:1186/1471-2350-15-16.

9. Girard D, Pertrovsky N (2011) Alstrom syndrome: insights into the pathogenesis of metabolic disorders. Nat Rev Endocrinol 7(2):77-88. doi: 10.1038/nrendo.2010.210. 
10. Sugimoto M (2014) A cascade leading to premature aging phenotypes including abnormal tumor profiles in Werner syndrome (review). Int J Mol Med 33(2):247-253. doi:10.3892/ijmm.2013.1592.

11. Ahmed MS, Ikram S, Bibi N, Mir A (2017) Hutchinson-Gilford Progeria Syndrome: a premature aging disease. MolNeurobiol Jun 28 doi:10.1007/s12035-017-0610-7.

12. American Diabetes Association (2012) Diagnosis and classification of diabetes mellitus. Diabetes Care 35(1):S64-S71. doi:10.2337/dc12-s064.

13. Laakso M, Kuusisto J (2014) Insulin resistance and hyperglycaemia in cardiovascular disease development. Nat Rev Endocrinol 10(5):293-302.

14. Kong AP, Xu G, Brown N, So WY, Ma RC, Chan JC (2013) Diabetes and its comorbidities - where East meets West. Nat Rev Endocrinol 9(9):537-547. doi:10.1038/nredo.2013.102.

15. Pugliese G, Solini A, Bonora E, Fondelli C, Orsi E, Nicolucci A, Penno G, RIACE Study Group (2014) Chronic kidney disease in type 2 diabetes: lessions from the Renal Insufficiency And Cardiovascular Events (RIACE) Italian Multicentre Study. NutrMetabCardiovasc Dis 24(8):815-822. doi:10.1016/j.numecd2014.02.013.

16. Sacks FM, Hermans MP, Fioretto P, Valensi P, Davis T, Horton E, Wanner C, AlRubeaan K, Aronson R, Barzon I, Bishop L, Bonora E, Bunnag P, Chuang LM, Deerochanawong C, Goldenberg R, Harshfield B, Hernández C, Herzlinger-Botein S, Itoh H, Jia W, Jiang YD, Kadowaki T, Laranjo N, Leiter L, Miwa T, Odawara M, Ohashi K, Ohno A, Pan C, Pan J, Pedro-Botet J, Reiner Z, Rotella CM, Simo R, Tanaka M, Tedeschi-Reiner E, Twum-Barima D, Zoppini G, Carey VJ (2014) Association between plasma triglycerides and high-density lipoprotein cholesterol and microvascular kidney disease and retinopathy in type 2 diabetes mellitus: a global case-control study in 13 countries. Circulation 129(9):999-1008 doi: 10.1161/CIRCULATIONAHA.113.002529.

17. Salvotelli L, Stoico V, Perrone F, Cacciatori V, Negri C, Brangani C, Pichiri I, Targher G, Bonora E, Zoppini G (2015) Prevalence of neuropathy in type 2 diabetic patients and its association with other diabetes complications: The Verona Diabetic Foot Screening Programme. J Diabetes Complications 29(8):2066-1070. doi: 10.1016/j.jdiacomp.2015.06.014.

18. Baltzis D, Eleftheriadou I, Veves A (2014) Pathogenesis and treatment of impaired wound healing in diabetes mellitus: new insights. AdvTher 31(8):817-836. doi:10.1007/s12325-014-0140-x. 
19. Tsourdi E, Barthel A, Rietzsch H, Reichel A, Bornstein SR (2013) Current aspects in the pathophysiology and treatment of chronic wounds in diabetes mellitus. Biomed Res Int 2013:385641. doi 10.1155/2013/385641.

20. Zhang P, Lu J, Jing L, Tang S, Zhu D, Bi Y (2017) Global epidemiology of diabetic foot ulceration: a systematic review and meta-analysis. Annals of Medicine 49(2):106116.

21. Ansell DM, Holden KA, Hardman MJ (2012) Animal models of wound repair: are they cutting it? Experimental Dermatology 21:581-585. doi10.1111/j.16000625.2012.01540.x.

22. Zomer HD, Trentin AG (2018) Skin wound healing in humans and mice: Challenges in translational research. Journal of Dermatological Science 90:3-12.Doi: 10.1016/j.dermsci.2017.12.009.

23. Malone AG, Brudno Y, Stojadinovic O, Park LK, Smith A, Tellechea A, Leal EC, Kearney CJ, Veves A, Tomic-Canic M, Mooney DJ, Garlick JA (2015) Threedimensional human tissue models that incorporate diabetic foot ulcer-derived fibroblasts mimic in vivo features of chronic wounds. Tissue Engineering 21(5): 499-508. Dio:10.1089/ten.tec.2014.0414.

24. Golebiewski EM, Poole WM (2015) Platelet secretion: From hemostasis to wound healing and beyond. Blood Rev 29(3): 153-162. doi: 10.1016/i.blre.2014.10.003.

25. Bielefeld KA, Ameni-Nik S, Alman BA (2013) Cutaneous wound healing: recruiting developmental pathways for regeneration. Cell Mol Life Sci 70:2059-2081. doi: 10.1007/s00018-012-1152-9.

26. Martin P, Nunan R (2015) Cellular and molecular mechanisms of repair in acute and chronic wound healing. Br J Dermatol 173(2):370-378. doi:10.1111/bjd.13954.

27. Ahmed M, de Winther MPJ, Van den Bossche J (2017) Epigenetic mechanisms of macrophage activation in type 2 diabetes. Immunobiology 222(10):937-943. doi:10.1016/j.imbio.2016.08.011.

28. Wicks K, Torbica T, Mace KA (2014) Myeloid cell dysfunction and the pathogenesis of the diabetic chronic wound. Seminlmmunol 26(4):341-353. doi:10.1016/j.smim.2014.04.006.

29. Nunan R, Harding KG, Martin P (2014) Clinical challenges of chronic wounds: searching for an optimal animal model to recapitulate their complexity. Dis Model Mech 7(11):1205-1213. doi:10.1242/dmm.016782. 
30. Peppa M, Raptis SA (2011) Glycoxidation and wound healing in diabetes: an interesting relationship. Curr Diabetes Rev 7(6):416-425. doi:10.2174/157339911797579188.

31. Cory G (2011) Scratch-wound assay. Methods MolBiol 769:25-30. doi: 10.1007/978-1-61779-207-62.

32. Buth H, Wolters B, Hartwig B, Meier-Bornheim R, Veith H, Hansen M, Sommerhoff CP, Schaschke N, Machledit W, Fusenig NE, Boukamp P, Brix K (2004) HaCaT keratinocytes secreted lysosomal cysteine proteinases during migration. Eur $\mathrm{J}$ Cell Biol 83(11-12): 781-795. doi:10.1078/0171-9335-00428.

33. Buth $\mathrm{H}$, LiuigiButtigieg $\mathrm{P}$, Ostafe R, Rehders M, Dannenemann SR, Schashcke N, Stark HJ, Boupkamp P, Brix K (2007) Cathepsin B is essential for regeneration of scratch-wounded normal human epidermal keratinocytes. Eur J Cell Biol 86(1112):747-761. doi: 10.1016/j.ejcb.2007.03.009.

34. Wright CS, van Steensel MA,. Hodgins, MB, Martin PE (2009) Connexin mimetic peptides improve cell migration rates of human epidermal keratinocytes and dermal fibroblasts in vitro. Wound Repair Regen 17(4):629. doi:10.1111/j.1524475X.2009.00471.X

35. Pollok S, Pfeiffer AC, Lobmann R, Wright CS, Moll I, Martin PE, Brandner JM (2011) Connexin 43 mimetic peptide Gap 27 reveals potential differences in the role of $\mathrm{Cx} 43$ in wound repair between diabetic and non-diabetic cells. J Cell Mol Med 15(4);861-873. Doi:10.1111/j.1582-4934.2010.01057.x

36. Wright CS, Pollok S, Flint DJ, Brandner JM, Martin PE (2012) The connexin mimetic peptide Gap27 increases human dermal fibroblast migration in hyperglycaemic and hyperinsulinemic conditions in vitro. J Cell Physiol 227(1):77-87. doi:10.1002/jcp.22705.

37. Wright CS, Berends RF, Flint DJ, Martin PE (2013) Cell motility in models of wounded human skin is improved by Gap27 despite raised glucose, insulin and IGFBP5. Exp Cell Res 319(4):390-4041. doi: 10.1016/j.yexcr.2012.12.013.

38. Faniku C, O'Shaughnessy E, Lorraine C, Johnstone SR, Graham A, Greenhough S, Martin PE (2018) The connexion mimetic peptide Gap 27 and Cx43-knockdown reveal differential roles for connexion 43 in wound closure events in skin model systems. Int $\mathrm{J}$ MolSci 19(2). Pii.E604. doi:103390/ijms19020604.

39. Abaci HE, Guo Z, Coffman A, Gillette B, Lee WH, Sia SJ, Christiano AM (2016) Human skin constructs with spatially controlled vasculature using primary and iPSC- 
derived endothelial cells. AdvHealthc Mater 5(14): 1800-1807. doi:10.1002/adhm.201500936.

40. Abaci HE, Guo Z, Doucet Y, Jackow J, Christiano A (2017) Next generation human skin constructs as advanced tools for drug development. Experimental Biology and Medicine 242(17):1657-1668. doi:10.1177/1535370217712690.

41. Kandyba EE, Hodgins MB, Martin PE (2008) A murine living skin equivalent amenable to live-cell imaging: analysis of the roles of connexins in the epidermis. $J$ Invest Dermatol 128(4):1039-1049. doi:10.1038/sj.jid.5701125.

42. Wiegland C, Hewitt NJ, Merk HF, Reisinger K (2014) Dermal xenobiotic metabolism: a comparison between native human skin, four in vitro skin test systems and a liver system. Skin PharmacolPhysiol 27(5):263-275. doi: 10.1159/000358272.

43. Faller C, Bracher M, Dami N, Roquet R (2002) Predictive ability of reconstructed human epidermis equivalents for the assessment of skin irritation of cosmetics. Toxicolln Vitro 16(5): 557-572.

44. Lotte C, Patouillet C, Zanini M, Messager A, Roquet R (2002) Permeation and skin absorption: reproducibility of various industrial reconstructed human skin models. Skin PharmacolAppl Skin Physiol 15 Suppl 1: 18-30. doi:10.1159/0000666679.

45. Roquet R (2002) The use of standardised human skin models for cutaneous pharmacotoxicology studies. Skin PharmacolAppl Skin Physiol 15 Suppl 1:1-3. doi:10.1159/000066681.

46. Mewes KR, Raus M, Bernd A, Zoller NN, Sattler A, Graf R (2007) Elastin expression in a newly developed full-thickness skin equivalent. Skin PharmcolPhysiol 20(2):85-95. doi:10.1159/000097655.

47. Steinberg JS, Edmonds M, Hurley DP Jr, King WN (2010) Confirmatory data from EU study supports Apligraf for the treatment of neuropathic diabetic foot ulcers. J Am Poediatr Med Assoc 100(1):73-77.

48. Yazdanpanah L, Nasiri M, Adarvishi S (2015) Literature review on the management of diabetic foot ulcer. World J Diabetes 6(1):37-53. doi:10.4239/wjd.v6.i1.37.

49. Groeber F, Engelhardt L, Lange J, Kurdyn S, Schmid FF, Rucker C, Mielke S, Walles H, Hansmann J (2016) A first vascularised skin equivalent as an alternative to animal experimentation. ALTEX 33(4):415-422. doi: 10.14573/altex.1604041.

50. Gledhill K, Guo Z, Umegaki-Arao N, Higgins CA, Itoh M, Christiano AM (2015) Melanin transfer in human 3D skin equivalents generated exclusively from induced 
pluripotent stem cells. PloS One 10:e0136713. doi: 10.1371/journal.pone.0136713.eCollection 2015.

51. Hu S, Kirsner RS, Falanga V, Phillips T, Eaglstein WH (2006) Evaluation of Apligraf persistence and basement membrane restoration in donor site wounds: a pilot study. Wound Repair Regen 14:427-433. doi: 10.1111/j.1743-6109.2006.00148.x.

52. Mansbridge J (2009) Tissue-engineered skin substitutes in regenerative medicine. CurrOpinBiotechnol 20(5):563-567. Doi:10.1016/j.copbio.2009.08.008.

53. Ceder R, Merne M, Staab CA, Nilsson JA, Hoog JO, Dressler D, Engelhart K, Grafstrom RC (2007) The application of normal, SV40 T-antigen-immortalised and tumour-derived oral keratinocytes, under serum-free conditions, to the study of the probability of cancer progression as a result of environmental exposure to chemicals. Altern Lab Anim 35(6):612-639.

54. Ansell DM, Campbell L, Thomason HA, Brass A, Hardman MJ (2014) A statistical analysis of murine incisional and excisional acute wound models. Wound Rep Reg 22(2):281-287. doi:10.1111/wrr.12148.

55. Pane JA, Coulson BS (2015) Lessons from the mouse: potential contribution of bystander lymphocyte activation by viruses to human type 1 diabetes. Diabetologia 58(6):1149-1159. doi: 10.1007/s00125-015-3562-3.

56. Al-Awar A, Kupai K, Veszelka M, Szucs G, Attieh Z, Murlasits Z, Torok S, Posa A, Varga C (2016) Experimental diabetes mellitus in different animal models. J Diabetes Res 2016:9051426 doi: 10.1155/2016/9051426.

57. Ianitti T, Graham A, Dolan S (2012) Increased central and peripheral inflammation and inflammatory hyperalgesia in Zucker rat model of leptin receptor deficiency and genetic obesity. ExpPhysiol 97(11):1236-1245. doi: 10.1113/expphysiol.2011.064220. 58. Blaber SI, Diaz J, Blaber M (2015) Accelerated healing in NONcNZO10/LtJ type 2 diabetic mice by FGF-1. Wound Repair Regen 23:538-549. doi: 10.1111/wrr.12305 59. Sharpe JR, Martin Y (2013). Strategies demonstrating efficacy in reducing wound contraction. Adv Wound Care (New Rochelle) 2, 167-175. doi: 10.1089/wound.2012.0378.

60. Rittie L (2016) Cellular mechanisms of skin repair in humans and other mammals. J Cell Commun Signal 10(2):103-120. doi: 10.1007/s12079-016-0330-1.

61. Park SA, Raghunathan CL, Shah NM, Teixeira L, Motta MJ, Covert J, Dubielzig R, Schurr M, Isseroff RR, Abbott NL, McAnulty J, Murphy CJ (2014) PDGF-BB does not 
accelerate healing in diabetic mice with splinted skin wounds. PLoS One 9:e104447. doi:10.1371/journal.pone.0104447.eCollection 2014.

62. Shunmugam VK, Tassi E, Schmidt MO, McNish S, Baker S, Attinger C, Wang H, Shara $\mathrm{N}$ and Wellstein $\mathrm{A}$ (2015) Utility of a human-mouse xenograft model and in vivo near-infrared fluorescent imaging for studying wound healing. Int Wound J 12(6): 699705. doi:10.1111/iwj.12205.

63. Martinez-Santamaria L, Guerrero-Aspizua S, Del Rio M (2012) Skin bioengineering: preclinical and clinical applications. ActasDermosifiliorgr 103(5):5-11. doi:10.1016/j.adengyl.2011.03.016.

64. Martinez-Santamaria L, Conti CJ, Llames S, Garcia E, Retamosa L, Holquin A, Illera N, Duarte B, Cambio L, Llaneza JM, Jorcano JL, Larcher F, Meana A, Escamez MJ, Del Rio M (2013) The regenerative potential of fibroblasts in a new diabetes-induced delayed humanised wound healing model. ExpDermatol 22(3):195-201. doi: 10.1111/exd.12097.

65. Gurdon JB (1960a). Factors responsible for the abnormal development of embryos obtained by nuclear transplantation in Xenopuslaevis. J EmbryolExpMorphol 8: 327-340. 66. Gurdon JB (1960b). The developmental capacity of nuclei taken from differentiating endoderm cells of Xenopuslaevis. J EmbryolExpMorphol 8: 505-526.

67. Gurdon JB, Laskey RA (1970). The transplantation of nuclei from single cultured cells into enucleate frogs' eggs. J EmbryolExpMorphol 24: 227-248.

68. Takahashi K, Yamanaka S (2006). Induction of pluripotent stem cells from mouse embryonic and adult fibroblast cultures by defined factors. Cell126: 663-676. doi: 10.1016/j.cell,2006.07.024

69. Takahashi K., Okita K., Nakagawa M, Yamanaka S (2007a). Induction of pluripotent stem cells from fibroblast cultures. Nat Protoc 2: 3081-3089. doi : 10.1038/nprot.2007.418

70. Takahashi K, Tanabe K, Ohnuki M, Narita M, Ichisaka T, Tomoda K, Yamanka S (2007b). Induction of pluripotent stem cells from adult human fibroblasts by defined factors. Cell 131: 861-872. doi:10.1016/j.cell.2007.11.019.

71. Yu J, Vodyanik MA, Smuga-Otto K, Antosiewicz-Bourget J, Frane JL, Tian S, Nie J, Jonsdottir GA, Ruotti V, Stewart R, Slukvin II, Thomson JA (2007) Induced pluripotent stem cell lines derived from human somatic cells. Science 318(5858):1917-1920. doi: 10.1126/science. 1151526 . 
72. Wallet MA, Santostefano KE, Terada N, Brusko TM (2017) Isogenic cellular systems model the impact of genetic risk variants in the pathogenesis of Type 1 diabetes. Front Endocrinol 8:287. doi:10.3389/fendo.2017.00276.

73. Shi Y, Inoue H, Wu JA, Yamanaka S (2017) Induced pluripotent stem cell technology: a decade of progress. Nat Rev Drug Discov 16(20:115-130. doi:10.1038/nrd.2016.245.

74. Shtrichman R, Germanquz I, Itskovita-Eldor J (2013) Induced pluripotent stem cells (iPSCs) derived from different cell sources and their potential for regenerative and personalized medicine. CurrMol Med 13(5):792-805.

75. Maherali N, Hochedlinger K (2008) Guidelines and techniques for the generation of induced pluripotent stem cells. Cell Stem Cell 3: 595-605. Doi: 10.1016/j.stem.2008.11.008.

76. Steinle H, Behring A, Schlensak C, Wendel HP, Avci-Adali M (2017) Concise review: application of in vitro transcribed messenger RNA for cellular engineering and reprogramming: progress and challenges. Stem Cells 35(1):68-79. doi:10.1002/stem.2401.

77. Hu C, Li L (2016) Current reprogramming systems in regenerative medicine: from somatic cells to induced pluripotent stem cells. Regen Med 11(1):105-132. doi:10.2217/rme.15.79.

78. Brouwer M, Zhou H, Kasri N (2016) Choices for induction of pluripotency: recent developments in human induced pluripotent stem cell reprogramming strategies. Stem Cell Rev 12(1): 54-72. doi:10.1007/s12015-015-9622-8.

79. Singh VK, Kumar N, Kalsan M, Saini A, Chandra R (2015) Mechanism of induction: induced pluripotent stem cells (iPSCs) J Stem Cells 10(1):43-62.

80. Buta C, David R, Dressel R, Emgard M, Fuchs C, Gross U, Healy L, Hescheler J, Kolar R, Martin U, Mikkers H, Muller FJ, Schneider RK, Seiler AE, Spielmann H, Weitzer G (2013) Reconsidering pluripotency tests: do we still need teratoma assays? Stem Cell Res 11(1):552-562. doi:10.1016/j.scr.2013.03.001

81. Siller R, Naumovska E, Mathapati S, Lycke M, Greenhough S, Sullivan GJ (2016) Development of a rapid screen for the endodermal differentiation potential of human pluripotent stem cells. Sci Rep 6:37178 doi:10.1038/srep37178.

82. Siller R, Greenhough S, Park IH, Sullivan GJ (2013) Modelling human disease with pluripotent stem cells. Curr Gene Ther 13(2):99-110. 
83. Siller R, Greenhough S, Naumovska E, Sullivan GJ (2015) Small-molecule-drive hepatocyte differentiation of human pluripotent stem cells. Stem Cell Reports 4(5):9399552. doi: 10.1016/j.stemcr.2015.04.001

84. Li HL, Fujimoto N, Sasakawa N, Shirai S, Ohkame T, Sakuma T, Tanaka M, Amano N, Watanabe A, Sakurai H, Yamamoto T, Yamanaka S, Hotta A (2015) Precise correction of the dystrophin gene in duchnenne muscular dystrophy patient induced pluripotent stem cells by TALEN and CRISPR-Cas9. Stem Cell Reports 4(1):143-154. Doi:10.1016/j.stemcr.2014.10.013.

85. Seah YF, Farran EL, Warrier T, Xu J, Loh YH (2015) Induced pluripotency and gene editing in disease modelling: perspectives and challenges. In J MolSci 16(12):2861434. doi: 10.3390/ijms161226119.

86. Marro S, Yang N (2014) Transdifferentiation of mouse fibroblasts and hepatocytes to functional neurons. Methods MolBiol 1150:237-246. doi:10.1007/978-1-4939-05126_16.

87. Pennarossa G, Maffei S, Campagnol M, Tarantini L, Gandolfi F, Brevini TA (2013) Brief demethylation step allows the conversion of adult human skin fibroblasts into insulin-secreting cells. Proc Natl AcadSci USA 110(22):8948-53. doi:10.1073/pnas.1220637110.

88. Yang R, Zheng Y, Li L, Liu S, Burrows MP, Wei Z, Nace A, Heryln M, Cui R, Guo W, Cotsareli G, Xu X (2014) Direct conversion of mouse and human fibroblasts to functional melanocytes by defined factors. Nat Commun 5:5807. doi:10.10138/ncomms6807.

89. Amoh Y, Hoffman RM (2017) Hair follicle-assocated-pluripotent (HAP) stem cells. Cell Cycle 16(22):2169-2175. doi:10.1080/15384101.2017.1356513.

90. Peloso A, Dhal A, Zambon JP, Li P, Orlando G, Atala A, Soker S (2015) Current achievements and future perspectives in whole-organ bioengineering. Stem Cell Res Ther 6:107. doi:10.1186/s13287-015-0089-y.

91. Bilousova G, Roop DR (2014) Induced pluripotent stem cells in dermatology: potentials, advances and limitations. Cold Spring HarbPerspect Med 4(11):a015164. doi:10.1101/cshperspect.a015164.

92. Kogut I, Roop DR, Bilousova G (2014) Differentiation of human induced pluripotent stem cells into a keratinocyte lineage. Methods MolBiol 1195:1-12. doi:10.1007/7651_2013_64. 
93. Itoh M, Kiuru M, Cairo MS, Christiano AM (2011) Generation of keratinocytes from normal and recessive dystrophic epidermolysis bullosa-induced pluripotent stem cells. Proc Natl AcadSci USA 108(21):8797-802. doi.10.1073/pnase.1100332108.

94. Wenzel D, Bayerl J, Nystrom A, Bruckner-Tuderman L, Meixner A, Penninger JM (2014) Genetically corrected iPSCs as cell therapy for recessive dystrophic epidermolysis bullosa. SciTransl Med 6(284):264ra165. doi:10.1126/scitranslmed.3010083.

95. Prodinger CM, Reichelt J, Bauer JW, Laimer M (2017) Current and future perspectives of stem cell therapy in dermatology. Ann Dermatol 29(6):667-687. doi:10.5021/ad.2017.29.6.667.

96. Hirsch T, Rothoeft T, Teig N, Bauer JW, Pellegrini G, De Rosa L, Scaglione D, Reichelt J, Klausegger A, Kneisz D, Romano O, Second SEconetti A, contin R, Enzo E, Jurman I, Carulli S, Jacobsen F, Luecke T, Lehnhardt M, Fischer M, Kuelckelhaus M, Quaglino D, Morgante M, Bicciato S, Bondanza S, De Luca M (2017) Regeneration of the entire human epidermis using transgenic stem cells. Nature 551(7680):327-332. doi:10.1038/nature24487.

97. Aasen T, Raya A, Barrero MJ, Garreta E, Consiglio A, Gonzalez F, Vassena R, Bilic J, Pekarik V, Tiscornia G, Edel M, Boue S, Izpisua Belmonte JS (2008) Efficient and rapid generation of induced pluripotent stem cells from human keratinocytes. Nat Biotechnol 26(11):1276-1284. doi:10.1038/nbt.1503.

98. Utikal J, Polo JM, Stadtfeld M, Maherali N, Kulalert W, Walsh RM, Khalil A, Rheinwald JG, Hochedlinger K (2009) Immortalization eliminates a roadblock during cellular reprogramming into iPS cells. Nature 460(7259):1145-48. doi:10.1038/nature08285.

99. Kim K, Doi A, Wen B, Ng K, Zhao R, Cahan P, Kim J, Arvee MJ, Ji H, Ehrlich LI, Yabuuchi A, Takeuchi A, Cunniff KC, Hongguang H, McKinney-Freeman S, Naveiras O, Yoon TJ, Irizarry RA, Jung N, Seita J, Hanna J, Murakami P, Jaeisch R, Weissleder R, Orkin SH, Weissman IL, Feinberg AP, Daley GQ (2010) Epigenetic memory in induced pluripotent stem cells. Nature 467(7313):285-290. doi:10.1038/nature09342.

100. Marion RM, Strati K, Li H, Tejera A, Schoeftner S, Ortega S, Serrano M, Blasco MA (2009) Telomere acquire embryonic stem cell characteristics in induced pluripotent stem cells. Cell Stem Cell 4(2):141-54. doi: 10.1016/j.stem.2008.12.010. 
101. Prigione A, Fauler B, Lurz R, Lehrach H, Adjaye J (2010) The senescencerelated mitochondrial/oxidative stress pathway is repressed in human induced pluripotent stem cells. Stem Cells 28(4):721-733. doi: 10.1002/stem.404.

102. Lapasset L, Milhavet O, Prieur A, Besnard E, Babled A, Ait-Hamou N, Leschik J, Pellesttor F, Ramirez JM, De Vos J, Lehmann S, Lemaitre JM (2011) Rejuvenating senescent and centenarian human cells by reprogramming through the pluripotent state. Genes Dev 25(21):2248-2253. doi:10.1101/gad.173922.111.

103. Nissan X, Larribere L, Saidani M, Hurbain I, Delevoye C, Feteira J, Lemaitre G, Peschanski M, Baldeschi C (2011) Functional melanocytes derived from human pluripotent stem cells engraft into pluristratified epidermis. Proc Natl AcadSci USA 108(36): 14861-6. doi:10.1073/pnas.1019070108.

104. Hewitt KJ, Shamis Y, Hayman RB, Margvelashvili M, Dong S, Carlson MW, Garlick JA (2011) Epigenetic and phenotype profile of fibroblasts derived from induced pluripotent stem cells. PLoS One 6(2):e17128. doi: 10.1371/journal,pone.0017128.

105. Van den Broek LJ, Bergers LIJC, Reijnders CMA, Gibbs S (2017) Progress and future prospective in skin-on-chip development with emphasis on the use of different cell types and technical challenges. Stem Cell Rev 13(3):418-429. doi: 10.1007/s12015-017-9737-1.

106. Guo Z, Higgins CA, Gillette BM, Itoh M, Umegaki N, Gledhill K, Sia SK, Christiano AM (2013) Building a microphysiological skin model from induced pluripotent stem cells. Stem Cell Res Ther 4 Suppl 1:S2. doi: 10.1186/scrt363.

107. Itoh M, Umegaki-Arao N, Guo Z, Liu L, Higgins CA, Christiano AM (2013) Generation of $3 D$ skin equivalents fully reconstituted from human induced pluripotent stem cells (iPSCs). PLoS One 8(10):e77673. doi:10.1371/journal.pone.0077673.

108. Veraitch O, Kobayashi T, Imaizumi Y, Akamatsu W, Saski T, Yamanaka S, amagai M, Okano H, Ohyama M (2013) Human induced pluripotent stem cell-derived ectodermal precursor cells contribute to hair follicle morphogenesis in vivo. J Invest Dermatol 133(6):1479-88. doi:10.1037/jid.2013.7.

109. Petrova A, Celli A, Jacquet L, Dafou D, Crumrine D, Hupe M, Arno M, Hobbs C, Cvoro A, Karagiannis P, Devito L, Sun R, Adame LC, Vaughan R, McGrath JA, Mauro TM, Ilic D (2014) 3D in vitro model of a functional epidermal permeability barrier from human embryonic stem cells and induced pluripotent stem cells. Stem Cell Reports 2(5):675-689. doi:10.1016/j.stemcr.2014.03.009. 
110. Kim KL, Song SH, Choi KS, Suh W (2013) Cooperation of endothelial and smooth muscle cells derived from human induced pluripotent stem cells enhances neovascularisation in dermal wounds. Tissue Eng Part A 19(21-22): 2478-85. doi: 1.1089/ten.TEA.2012.0768.

111. Hu GW, Li Q, Niu X, Hu B, Liu J, Zhou SM, Guo SC, Lang HL, Zhang CQ, Wang Y, Deng ZF (2015) Exosomes secreted by human-induced pluripotent stell cellderived mesenchymal stem cells attenuate limb ischemia by promoting angiogenesis in mice. Stem Cell Res Ther 6:10 doi:10.1186/scrt546.

112. Paull D, Sevilla A, Zhou H, Hahn AK, Kim H, Napolitano C, Tsankov A, Shang L, Krumholz K, Jagadeesan P, Woodard CM, Sun B, Vilboux T, Zimmer M, Forero E, Moroziewicz DN, Martinez H, Malicdan MC, Weiss KA, Vensand LB, Dusenberry CR, Polus H, Sy KT, Kahler DJ, Gahl WA, Solomon SL, Chang S, Meissner A, Eggan K, Noggle SA (2015) Automated, high-throughput derivation, characterization and differentiation of induced pluripotent stem cells. Nat Methods 12(9):885-892. doi: 10.1038/nmeth.3507.

113. Schuster J, Halvardson J, Lorenzo P, Ameur A, Sobol M, Raykova D, Anneren G, Feuk L, Dahl N (2015) Transcriptome profiling reveals degree of variability in induced pluripotent stem cell lines: impact for human disease modelling. Cell Reprogram 17(5):327-37. doi: 10.1089/cell.2015.0009.

114. Ruiz S, Lopez-Contreras AJ, Gabut M, Marion RM, Gutierrez-Martinez P, Bua S, Ramirez O, Olade I, Rodrigo-Perez S, Li H, Marques-Bonet T, Serrano M, Blasco MA, Batada NN, Fernandez-Capetillo O (2015) Limiting replication stress during somatic cell reprogramming reduces genomic inability in induced pluripotent stem cells. Nat Commun 6:8036. doi: 10.1038/ncomms9036.

115. vonJoest M, Bua Aguin S, Li H (2016) Genomic stability during cellular reprogramming: mission impossible? Mutat Res 788:12-6. doi:10.1016/j.mrfmmm.2016.01.001.

116. Fujikura J, Nakao K, Sone M, Noguchi M, Mori E, Naito M, Taura D, HaradaShiba M, Kishimoto I, Watanabe A, Asaka I, Hosoda K, Nakao K (2012) Induced pluripotent stem cells generated from diabetic patients with mitochondrial DNA A3243G mutation. Diabetologia 55(6):1689-98. doi:10.1007/s00125-012-2508-2.

117. Matsubara $M$, Kanda $H$, Imamura $H$, Inoue $M$, Noguchi $M$, Hosoda K, Kakizuka A, Nakao K (2018) Analysis of mitochondrial function in human induced 
pluripotent stem cells from patients with mitochondrial diabetes due to the A3243G mutation.Sci Rep 8:949. doi: 10.1038/s41598-018-19264-7.

118. Teo AJJJ, Windmueller R, Johansson BB, Dirice E, Njolstad PR, Tjora E, Raeder H, Kulkarni RN (2012) Derivation of human induced pluripotent stem cells from patients with Maturity Onset Diabetes of the Young. J BiolChem 288(8):5353-5356. doi: $10.1074 / j b c C 112428979$.

119. Griscelli F, Ezanno H, Soubeyrand M, Feraud O, Oudrhiri N, Bonnefond A, Turhan AG, Froquel P, Bennaceur-Griscelli A (2018) Generation of an induced pluripotent stem cell (iPSC) line from a patient with maturity-onset diabetes of the young type 3 (MODY3) carrying a hepatocyte nuclear factor 1-alpha (HNF1A) mutation. Stem Cell Res 29:56-59. doi: 10.1016/j.scr.2018.02.017.

120. Rajaei B, Shamsara M, Sanati MH (2017) In vitro generation of glucoseresponsive insulin-secreting cells from pancreatic and duodenal homeobox 1 overexpressing human-induced pluripotent stem cell derived from diabetic patient. ASAIO J doi: 10.1097/MAT.0000000000000728. [Epub ahead of print].

121. Wang X, Chen S, Burtscher I, Sterr M, Hieronimus A, Machicao F, Staiger H, Haring HU, Lederer G, Meitinger T, Lickert $H$ (2016) Generation of a human indicated pluripotent stem cell (iPSC) line from a patient with family history of diabetes carrying a C18R mutation in the PDX1 gene. Stem Cell Res 17(2): 292-295. doi: 10.1016/j.scr.2016.08.005.

122. Teo AK, Lau HH, Valdez IA, Dirice E, Tjora E, Raeder H, Kulkarni RN (2016) Early developmental perturbations in a human stem cell model of MODY5/HNF1B pancreatic hypoplasia. Stem Cell Reports 6(3):357-367. doi: 10.1016/j.stemcr.2016.01.007

123. Yabe SG, Iwasaki N, Yasuda K, Hamazaki TS, Konno M, Fukuda S, Takeda F, Kasuga M, Okochi H (2015) Establishment of maturity-onset diabetes of the younginduced pluripotent stem cells from a Japanese patient. J Diabetes Investig 6(5):543-7. doi: $10.1111 /$ jdi.12334.

124. Griscelli F, Feraud O, Emault T, Oudrihri N, Turhan AG, Bonnefond A, Froguel P, Bennaceur-Griscelli A (2018) Generation of an induced pluripotent stem cell (iPSC) line from a patient with maturity-onset diabetes of the young type 13 (MODY13) with a potassium inwardly-rectifying channel, subfamily $\mathrm{J}$, member 11 (KCNJ11) mutation. Stem Cell Res 23:178-181. doi: 10.1016/j.scr.2017.07.023. 
125. Toustrup LB, Zhou Y, Kyistgaard H, Gregersen N, Rittig S, Aagaard L, Corydon TJ, Luo Y, Christensen JH (2017) Induced pluripotent stem cells derived from a patient with autosomal dominant familial neurohypophyseal diabetes insipidus caused by a variant in the AVP gene. Stem Cell Res 19:37-42. doi: 10.1016/j.scr.2016.12.021.

126. Saarimaki-Vire J, Balboa D, Russell MA, Saarikettu J, Kinnunen M, Keskitalo S, Malhi A, Valensisi C, Andrus C, Eurola S, Grym H, Ustinov J, Wartiovaara K, Hawkins RD, Silvennoinen O, Varjosalo M, Morgan NG, Otonkoski T (2017) An activating STAT3 mutation causes neonatal diabetes through premature induction of pancreatic differentiation. Cell Rep 19(2):281-294. doi: 10.1016/j.celrep.2017.03.055 127. Burkart AM, Tan K, Warren L, lovino S, Hughes KJ, Kahn CR, Patti ME (2016) Insulin resistance in human iPS cells reduces mitochondrial size and function. Sci Rep 6:22788. doi: 10.1038/srep22788.

128. Burnett LC, LeDuc CA, Sulsona CR, Paull D, Eddiry S, Levy B, Salles JP, Tauber M, Driscoll DJ, Egli D, Leibel RL (2016) Induced pluripotent stem cells (iPSC) created from skin fibroblasts of patients with Prader-Willi syndrome (PWS) retain the molecular signature of PWS. Stem Cell Res 17(3):526-530. doi: 10.1016/j.scr.2016.08.008

129. Nissan X, Blondel S, Peschanski M (2011) In vitro pathological modelling using patient-specific induced pluripotent stem cells: the case of progeria. BiochemSoc Trans 39 (6): 1775-9. doi: 10.1042/BST20110659.

130. Mori E, Fujikura J, Noguchi M, Nakao K, Matsubara M, Sone M, Taura D, Kusakabe T, Ebihara K, Tanaka T, Hosoda K, Takahashi K, Asaka I, Inagaki N, Nakao K (2016) Metabolism 65(4):543-556. doi: 10.1016/j.metabol.2015.12.015.

131. Hosokawa Y, Toyoda T, Fukui K, Baden MY, Funato M, Kondo Y, Sudo T, Iwahashi H, Kishida M, Okada C, Watanabe A, Asaka I, Osafune K, Imagawa A, Shimomura I (2017) Insulin-producing cells derived from 'induced pluripotent stem cells' of patients with fulminant type 1 diabetes: Vulnerability to cytokine insults and increased expression of apoptosis-related genes. J Diabetes Invest Aug 10: doi: 10.1111/jdi.12727. [Epub ahead of print].

132. Liu J, Joglekar MV, Sumer H, Hardikar AA, Teede H, Verma PJ (2014) Integration-free human induced pluripotent stem cells from type 1 diabetes patient skin fibroblasts show increased abundance of pancreas-specific microRNAs. Cell Med 7(1):15-24. doi: 10.3727/215517914X681785. 
133. Chan XY, Black R, Dickerman K, Federico J, Levesque M, Mumm J Gerecht $S$ (2015) Three-dimensional vascular network assembly from diabetic patient-derived induced pluripotent stem cells. ArteriosclerThrombVascBiol 35(12):2677-85. doi: 10.1161/ATVBAHA.115.306362.

134. Gerami-Naini B, Smith A, Maione AG, Kashpur O, Carpinito G, Veves A, Mooney DJ, Garlick JA (2016) Generation of induced pluripotent stem cells from diabetic foot ulcer fibroblasts using a nonintegrative Sendai virus. Cell Reprogrm 18(4):213-223. doi: 10.1089/cell.2015.0087.

135. Drawnel FM, Boccardo S, Prummer M, Delobel F, Graff A, Weber M, Gerard R, Badi L, Kam-Thong T, Bu L, Jiang X, Hoflack J-C, Kialainen A, Jeworutzki E, Aoyama N, Carlson C, Burcion M, Gromo G, Boehringer M, Stahlberg H, Hall BJ, Magnone MC, Kolaja K, Chien KR, Bailly J, lacone R (2014). Disease modelling and phenotypic drug screening for diabetic cardiomyopathy using human induced pluripotent stem cells. Cell Reports 9: 810-820. doi: 10.1016/j.celrep.2014.09.055.

136. Sun X, Yu W, Hu C (2014) Genetics of type 2 diabetes: insights into the pathogenesis and its clinical application. BioMed Research Int 2014:926713. doi: 10.1155/2014/926713.

137. Kwak SH, Park KS (2016) Recent progress in genetic and epigenetic research on type 2 diabetes. ExpMol Med 48:e220. doi: 10.1038/emm.2016.7.

138. Harvey AJ, O'Brien C, Lambshead J, Sheedy JR, Rathjen J, Laslett AL, Gardner DK (2018) Physiological oxygen culture reveals retention of metabolic memory in human induced pluripotent stem cells. PLoS ONE 13(3):e0193949. doi: 10.1371/journal.pone.0193949.

139. Loo LSW, Lau HH, Jasmen JB, Lim CS, Teo AKK (2018) An arduous journey from human pluripotent stem cells to functional pancreatic $\beta$-cells. Diabetes ObesMetab 20(1): 3-13. doi: 10.1111/dom.12996.

140. Rostovskaya M, Bredekamp N, Smith A (2015) Towards consistent generation of pancreatic lineage progenitors from human pluripotent stem cells. Philos Trans R SocLond B Biol Sci. 19;370(1680):20140365. doi: 10.1098/rstb.2014.036.

141. Chichagova V, Hallam D, Collin J, Buskin A, Saretzki G, Armstrong L, YuWai-Man P, Lako M, Steel DH (2017) Human iPSC disease modelling reveals functional and structural defects in retinal pigment epithelial cells harbouring the m3243A>G mitochondrial DNA mutation. Sci Rep 7(1):12320. doi: 10.1038/s41598-017-12396-2 
Patient Biopsy sample

-Diabetic/non-diabetic

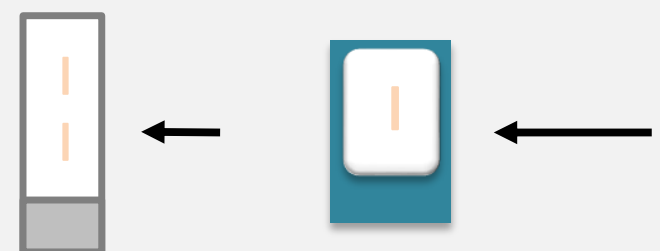

Wax embedding of tissue and sectioning

\section{Isolation of Cells from tissue}

$\longrightarrow$ Keratinocytes

$\longrightarrow$ Fibroblasts

Separation of Epidermis and

Dermis

Development of a 3D organotypic skin model with differentiated iPS cells

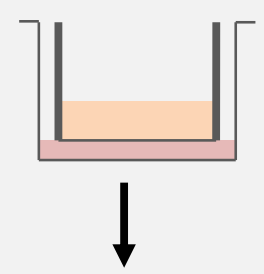

Wound healing studies in 3D model

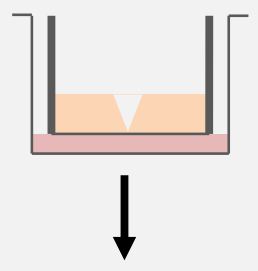

Drug Discovery

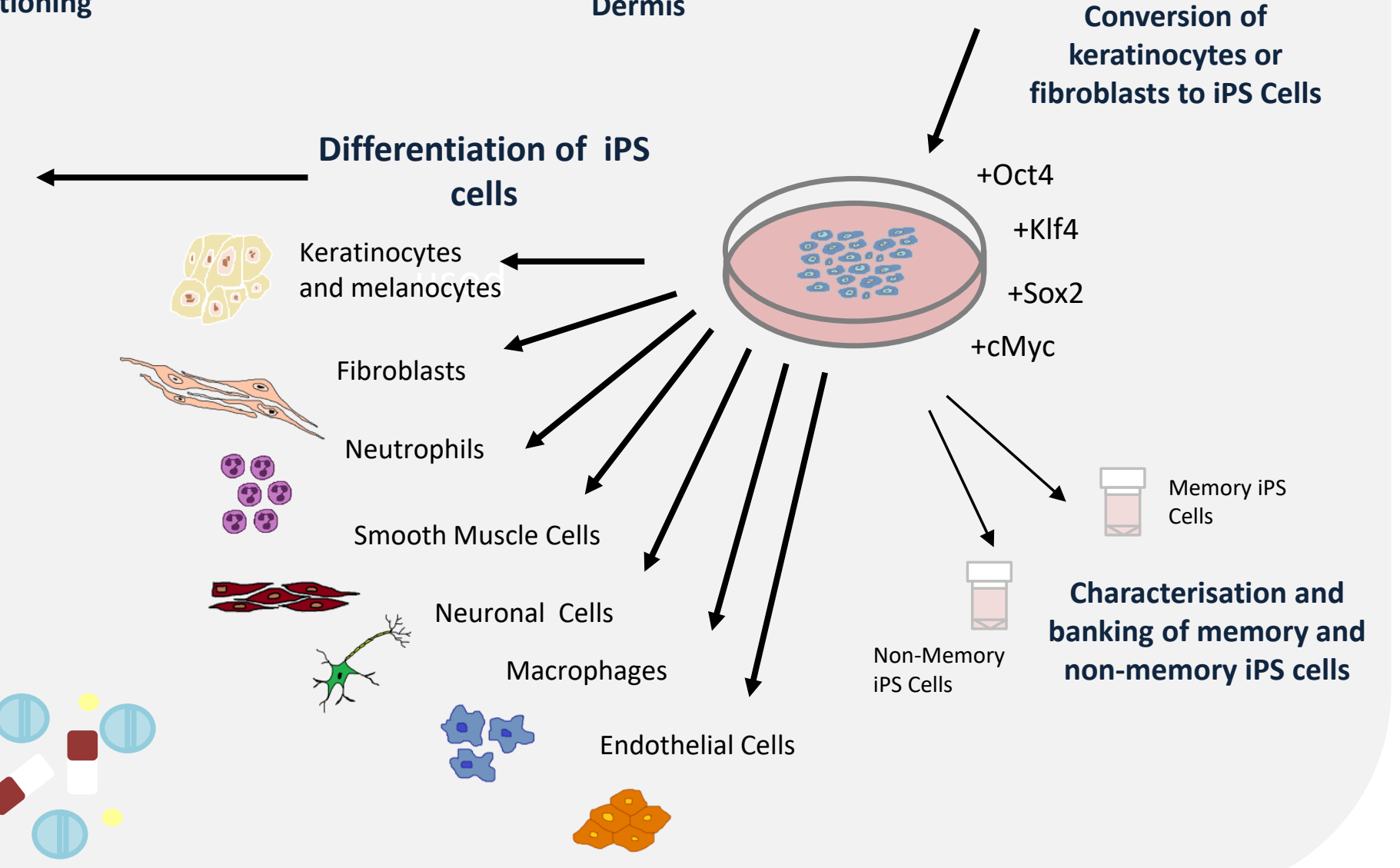

